\title{
FrenCH LAW OF Delict: The Role OF FAULT AND THE PRINCIPLES GOVERNING LOSSES AND REMEDIES
}

\author{
Yves-Louis Sage
}

The French law of delict is based on the fundamental concept of damage. Proof of damage is mandatory in delictual claims. The function of civil responsibility is first of all, to indemnify: it can be independent of fault, but it presupposes damage. Judicial compensation or reparation of the harm does not necessitate full compensation in every case as this may be influenced by insurance, other forms of compensation and general policy considerations. Compensation can be made either in kind or in money. The latter is easily quantified and effected, but compensation in kind is more difficult to achieve. The study of the evolution of civil liability clearly indicates a gradual and continuous transfer from fault to guarantee.

\section{Introduction}

Article 1370 of the French Civil Code, states that an obligation can arise as the consequence of a delict or a quasi-delict, which is different from the obligation which arises from personal commitment made in contractual relationships. The French Civil Code considers that a delict exists when the damage is intentionally inflicted ${ }^{\mathbf{1}}$; a quasi-delict is due to negligence, clumsiness, or imprudence. Article 1383 of the French Civil Code specifically refers to this distinction. However, from a practical perspective such an approach is irrelevant, because the same rules are applied to delicts and quasi-delict i.e. the duty to indemnify, the scope of the indemnification, and they do not change according to the nature of the origin of the damage ${ }^{2}$.

The French law of delict is based on the fundamental concept of damage. Therefore proof of damage is mandatory in delictual claims. The requirement of damage stems from the

* Maître de Conférences, French University of the Pacific, Honorary Fellow in Law Victoria University of Wellington.

1 Defamation is one example.

2 In fact, the only difference is the impossibility to buy an insurance contract for personal wrongdoing (article L.113-1 Insurance Code). 
primary delictual provisions of articles 1382,1383 and $1384^{3}$. These articles provide that the inherent basis of French civil liability ${ }^{4}$ is the compensation or indemnification of the victim. To fulfil this general objective damage is required.

Catala \& Weir state that: ${ }^{5}$

The function of civil responsibility is to indemnify: it can be independent of fault, but it presupposes damage. In French legal terminology, the words 'damage' (dommage) and 'harm' or 'injury' (préjudice ) are generally considered synonymous."

Compensation or reparation of the harm by the courts does not necessitate full compensation in every case as this may be influenced by insurance, other forms of compensation and general policy considerations. ${ }^{6}$ Automatic compensation through insurance and the state will be assumed not to jeopardise the principles governing the function of civil liability ${ }^{7}$. The concept of damage is part of the overall approach to French law. Thus, it relates to a number of other issues in the broader framework of delicts. First, the French law requires three elements: damage; causality and responsibility (fault) ${ }^{8}$. This paper will focus on damage 9 .

Second, the concept of damage is to be distinguished from damages. Damage is the harm or loss the plaintiff suffers, damages are the compensation recovered for such damage. Since a

3 Article 1382 Civil Code:

"Any act whatever of man causes damage to another obliges him by whose fault it occurred to make reparation."

Article 1383 Civil Code:

"Each one is liable for the damage which he causes not only by his own act but also by his negligence or imprudence."

Article 1384 Civil Code:

"A person is liable not only for the damage which he caused by his own act, but also for that which is caused by the act of persons for whom he is responsible, or by things which he has in his keeping."

4 On the meaning of the term "civil liability", see A. Tunc, "A codified law of tort :The French Experience", 39 Louisiana LRev, 1051, 1075, also E.A. Tomlinson "Tort liability in France for the act of things : A study of judicial law making" 48 Louisiana L R 1300, 1367.

5 Catala and Weir "Delict \& Torts: A Study in Parallel" (1964) 38 Tul L R 663.

6 R David English Law \& French Law (Stevens \& Sons, London, 1980). p.162. A. Tunc; Responsabilité (en général), Encyclopédie Dalloz $\mathrm{n}^{\circ} 1$ and seq. P. LE Tournaux - La responsabilité civile - DALLOZ 3ème Ed 1982 - $\mathrm{n}^{\circ} 158$ and seq. Weill et Terre Droit Civil - Les obligations Précis DALLOZ 4ème Ed - $1986-\mathrm{n}^{\circ} 752$ and seq. Chartier, La réparation du préjudice dans la responsabilité civile Traité Dalloz, 1983.

7 Constitutional Council, 22 October 1982, DS 1983, 189, Note Luchaire.

8 J. Huet - Responsabilité contractuelle et responsabilité délictuelle, essai de délimitation des deux ordres de responsabilité - Thèse Dacty PARIS II 1978.

9 However causality and fault are important issues. 
breach of a legitimate interest protected by the law exists and since the damage is actual and certain, it will provide legal grounds for compensation. However, the concept of damage remains subject to a case by case approach. The Civil Code does not indicate the limits of damage and so the courts determine this on the circumstances of each case. Damage can be either material or moral ${ }^{10}$.

If for the draftsmen of the French Civil Code, civil liability was intended to be the natural consequence of a fault, this conception is no longer valid today. However it does not mean that the fault has disappeared.

\section{Diversity of the types of damage which can be mended}

There are a number of different types of damage that could be mended. Tunc, believes that a host of issues arise on the concept of damage:

Are all kinds of damage capable of 'compensation' and which rules govern the assessment of such damage? How can one be compensated, for instance, for the loss of a spouse, a child, or an arm? If one's earning capacity is reduced, shall he be entitled to a lump sum or to periodic payments? Shall we take into account a mere reduction of his earning capacity or only an actual reduction of his earnings? What about the loss of a hope or an increased threat to ones health? ${ }^{11}$

These issues illustrate the difficulty of determining when damage has actually occurred and when it will be compensated. To provide an answer, requires a flexible case by case approach based on the material or moral damage distinction.

\section{A Types of Damage}

There are two types of damage for which liability may arise, namely material and moral damage. Material damage is less common but it is easier to prove. On the other hand, moral damage covers a greater array of situations, but its existence is more difficult to prove .

\section{Material Damage (Dommage materiel)}

Material damage can be defined as damage that affects the victim's rights of property. Catala \& Weir ${ }^{12}$ define material damage as injury to the patrimony, that is to the pecuniary interests of the injured party. This includes destruction or deterioration of a thing and injury to property. It has also been defined as including loss of earnings, permanent total or

10 This paper will not consider damages in relation to the borderline area of indirect victims.

11 A Tunc "A Codified Law of Tort-The French Experience." (1979) 39 Lousiana LR 1051, 1060.

12 Catala and Weir, above n 4, 671. 
partial disability and medical expenses ${ }^{13}$. Thus, it involves every kind of loss that is measurable in monetary terms. ${ }^{14}$

Material damage has always been considered as grounds for full reparation of the harm suffered. ${ }^{15}$ This includes not merely the economic loss suffered but also the opportunity costs from the gains or profits which have had to be foregone. ${ }^{16}$ Material damage cases are capable of valuation with a reasonable degree of precision. ${ }^{17}$

\section{Moral Damage (Dommage moral)}

Moral damage is more difficult to determine due to its inherent basis in human emotions. It represents the area in which courts have had the most difficulty in concluding the existence of damage.

Amos and Walton define moral damage as affecting only the victim's extra-patrimonial rights. This includes damage to honour, reputation or personal feelings. However, in some cases this may be difficult to determine. In cases involving injury to oneself or the death of a family member, moral damage may be more readily apparent than in situations of mental suffering caused by injury to loved ones. The courts have had to address these issues especially in regard to indirect victims and the courts face difficulties in balancing the need to allow genuine moral damage claims while preventing abuse by frivolous or vexatious claims that may lead to a flood of litigation. ${ }^{18}$

All courts now allow the reparation of moral damage. ${ }^{19}$ However, the administrative courts led by the Council of State were initially unwilling to allow reparation of moral

13 De Vries Civil Law and the Anglo-American Lawyer (Oceana Publications, New York, 1976) 330.

14 Amos \& Walton Introduction to French Law (3 ed, Oxford University Press, London, 1967) 209.

15 R Works "Comparative Approaches to Delictual Responsibility: The French \& The American Perspectives" (1967) 11 St Louis L J 587, 611.

16 Catala and Weir, above n4, 672.

17 Catala and Weir,above n4, 673.

18 Catala and Weir, above n4, 678-9. Catala and Weir consider a number of general policy arguments against compensating moral harm, first, that adequate amends may not be possible as monetary payments can not remove the pain and suffering and that monetary reparation may be inadequate for such damage.

19 See: Graham v. Western Union Telegraph Co. 34 So.91. 109La.1069 (1903). In Graham the court held on p92 that:"In France, not only do material injuries furnish ground for legal actions for redress, but so, also, do what are there referred to as 'moral injuries.' the doctrine rests there upon jurisprudence." See further: $\mathrm{S}$ Litvinoff "Moral Damages" (1977) 38 Louisiana L R 1. The Louisiana courts have recognised that moral damage can include fright, nervous shock and mental suffering.See: C.E.M.III "Offences \& Quasi Offences-mental suffering Resulting from Property Damages-Recovery Under Article 2315, Louisiana Civil Code of 1870" (1945) 19 Tul L Rev 636. A Montgomery "Fright or Nervous Shock as a Basis for the Recovery of Damage"(1938) 12 Tul L Rev 272. R Bassett "Offences \& Quasi Offences-Negligence-Independent Cause of Action for Mental Suffering" 
damage. The Council of State was reluctant to grant compensation due to the difficulties of measuring moral damage in monetary terms. This divergence has recently been remedied with the Council of State accepting the civil court's approach.

Overall, compensation can be sought where the plaintiff has suffered material or moral damage or both. Catala and Weir ${ }^{20}$ propose a third category of corporeal damage. This is a composite category where the victim suffers both material and moral damage contemporaneously.

"In all compensation of loss resulting from civil wrongs attributable to private persons, physical or legal, French law in no way consists of punitive regime, whatever the gravity of these wrongs". According to this principle the right of compensation exists from the moment when the loss is offered. There is one prior distinction which occurs depending upon how far matters have gone in relation to a contract. The party due to perform the contract is only bound to do so if performance has been commenced unless the contract is a matter of a succession of performances or an obligation not to perform. However, in matters of delict the right to compensation exists from the time when the loss occurs ${ }^{21}$. The right to compensation carries with it, among others, the following consequences:

- the victim has the option to take protective measures in order to avoid insolvency of the debtor;

- the Paulian action allows the victim or the heirs to render null and void any transaction which tends to create the insolvency of the debtor. The action is directed against the third party who has acquired the goods of the debtor (article 1167 of Civil Code) ${ }^{22}$;

- article 724 of the Code Civil codifies the principle of the transmission of the debt to heirs or sole legatees. The victim or his heirs can either have the amount of compensation set judicially, or they can settle with the debtor on agreeable compensation. We shall limit our investigations to judicial setting of liability. The first purpose of compensation by

(1961) 36 Tul L Rev 160. In Pecoraro v. Kopanica 173 So. 203 (La.App.1937) the court held that "[i]n Louisiana, however, it is settled that, even though there may be no actual objective symptoms of injury, there may be recovery for nervous shock if the evidence concerning such nervous condition is sufficient to warrant the belief that such injury was actually suffered."

20 Catala and Weir, above n4, 685. Catala and Weir provide the example where activities are calculated to cast doubt on someone's professional honour then may have material damage on business customers and clientele, and also moral damage. Similarly, in Marlene Dietrich $v$ Soc.France-Dimanche Cour d'Appel of Paris D.1955, 295 where the court held that Marlene Dietrich suffered both material and moral damage: The moral damage for the publication of the unedited memoirs that violated her privacy and material damage because she was intending to write her own memoirs and faced the risk that that would be compromised.

21 J. Carbonnier, Droit Civil, 4, Les Obligations (PUF, 1988) 305.

22 Y. Buffelan Lanore, Droit Civil, 2éme année (Masson 1986) $n^{\circ} 404$. 
the courts is to ensure, compensation which is as complete as possible, and which must also go towards total recompense of the loss.

Once the problem of assessing the amount of compensation and the form it is to take has been ruled on, that of determining who carries the burden of compensation follows.

\section{B The two possible forms of compensation}

Two processes of compensation are possible $\mathrm{e}^{23}$.

Compensation can be made either in kind or in money ${ }^{24}$. The latter is easily quantified and effected, but compensation in kind is more difficult to achieve and perhaps does not constitute a true method of compensation. The victim cannot refuse compensation in kind when it is offered to her by the defendant ${ }^{25}$. However, if it is not offered by the defendant, the plaintiff is not obliged to ask for it. In the absence of legislation, the courts can of their own choice order either compensation in kind or in money. In fact compensation in kind is rarely possible, except in the following cases which aim either to suppress illegal behaviour or to denounce to the public the schemes of the defendant:

- the case of defamation, a judgment against the defaming party with an order to publish a retraction of the false allegations ${ }^{26}$.

- in matters of improper or illegal building, the judges will order demolition ${ }^{27}$;

- in cases of disputes between neighbours, the judge can intervene to put a stop to the activity which is at the root of the dispute ${ }^{28}$;

- -equally, the nullification of a fraudulent act in the case of a Paulian action will be a means of suppressing illegal acts ${ }^{29}$. It could turn out in a particular case, such as abuse of position of a minor ( $\mathrm{dol}$ ), that compensation in kind would be more advantageous than money, since it could be considered as a privilege. In effect, if the nullity of the act is upheld, such as normally results under the laws of capacity, the minor ought to pay

E. Roujou de Boubée, Essai sur la notion de réparation LGDJ 1974.

Le Tourneau, op. cit. $n^{\circ} 1028$.

A decision of the third Civil Chamber of the Court of Cassation, seems to grant priority to the compensation in kind as far as it can be acheived, 3 Civil Chamber 7 June 1979, Bull.Civ. 1979; III, 95, $\mathrm{N}^{\circ} 124$.

TGI Paris 14 November 1980-D. 1981, 163, note Lindon.

Court of Cassation, Third Civil Chamber, 8 October 1974, Revue Trimestrielle de Droit Civil 1975, 331, note Giverdon.

Court of Appeal Aix en Provence, 1 Febrary 1971, Gaz Pal. 1971,1,302.

H. Sinay, Revue Trimestrielle de Droit Civil 1948-183. 
damages to the third party for the loss he has caused by his error. But, if the minor is insolvent, the third party would not be completely compensated. With the execution of the deed, he has not incurred any loss ${ }^{30}$.

The application of the principle of compensation by equivalence is called "dommagesintérêts".

When the damage is caused to tangible property, the sum of money paid allows the victim to make repairs to the damaged item, or to acquire something similar.

The rules relating to obligations concerning sums of money govern the allocation of damages and interest. Thus the court is free to decide that the compensation will take the form of an annuity and it is not bound by the pleadings of the plaintiff or the defendant. It could be decided that compensation in the form of an annuity, which constitutes compensation of a permanent nature, is the most suitable when the damage consists of a disability or work-related incapacity, in that it is then a matter of replacing a lost income, given that the situation continues over a period of time $\mathrm{e}^{31}$.

The case law of the Cour de Cassation according to which the courts can fix life interests, is very much limited by the provisions of the law of 27 December 1974 which, following lobbying by insurance companies, has removed a large part of their field of application $^{32}$.

It is to be noted that the law of 5 July $1985^{33}$ provides that it is open to the victim of a traffic accident to ask that the annuity awarded be replaced by a capital sum.

\section{Quantification and the burden of compensation}

The first aim of compensation is to ensure that it is equivalent to the loss. Though the principle is straightforward, its application gives rise to difficulties when the amount of the loss fluctuates ${ }^{34}$.

\section{A The rule of equivalence of the compensation in relation to the loss suffered.}

"The loss and nothing but the loss" is the maxim which underlies the rule.

30 J. Carbonnier, Droit Civil, 4, Les Obligations (PUF 1988) 94.

31 Court of appeal Paris, 10 November 1983-D-1984, 214, note Chartrier.

32 Court of Cassation, Mixed Chamber (2 decisions) 6 November 1974- JCP 1975, II, 17978, note Savatier.

33 Known as the "Badinter law".

34 Principles provided by articles 1350 to1352 of the French Civil Code prevent a new trial taking place after a final and binding decision granting compensation. However these principles are subjet to some compromise. It is sufficient to claim a new prejudice loss, which will appear as a new petition and not as a fluctuation of the initial loss. 
The fundamental principle is that the compensation match the loss ${ }^{35}$. According to this ideal, the judges must calculate the loss as accurately as possible, taking into account all those aspects brought to their attention.

The amount of damages will not then be subject to any limitation, in particular the limitation on foreseeable damages which applies in contract law, does not apply in matters of delict. The amount of compensation is independent of the gravity of the fault or fact at the origin of a damage. Accordingly a lump sum payment would not be awarded ${ }^{36}$. One can imagine that even the slightest of wrongs could therefore lead to a judgment for an enormous sum of damages. On the other hand, the judge cannot increase the damages in order to sanction the seriousness of the act. By the same token, neither the respective financial situations of the plaintiff and defendant are to be taken into account, nor the fact that the defendant is insured or not insured.

It should be noted that from time to time the courts take a few liberties with these principles. In effect, they sometimes have a tendency to give precedence to considerations of equity, or make insurers pay dearly. Providing that this is not stated overtly, their decision cannot be appealed, because the evaluation of the loss is a question of fact, and therefore is not subject to the inspection by the Cour de Cassation ${ }^{37}$. Conversely, insurers' lobbies groups have been able to obtain from the powers that be rules fixing compensation at very low levels in contract law as much as in delict ${ }^{38}$.

Another fundamental principle is that the compensation can be neither less than nor greater than the loss. As a consequence, when the object which has been destroyed was second-hand, the plaintiff has the right to the monetary value of a similar object. But this principle is not applicable in every case. When the property destroyed is a motor vehicle it will generally be possible to find a vehicle of the same age and type on the second hand market, and the plaintiff will thus be placed in the situation where they were previously. But suppose that a truck, in colliding with a house, causes such damage that it is necessary to demolish the house and rebuild it. The house cannot be rebuilt in its exact state; it will, out of necessity, be brand new. The Cour of Cassation decided a long time ago that it is necessary, even in such a case, to apply the principle, and in so doing make a corresponding deduction for the wear and tear of the destroyed house from the cost of the reconstruction.

35 Cass Civ II 28 Oct 1954, JCP 55 - Ed G II, 8765, note Savatier.

36 Cass Crim 06 Dec. 1983 Bull Crim n 329 JCP 84 Ed G IV 55. Cass Com 17 nov 1987 SARL Armor Bétail et Autres c/ Banque Hervet.

37 J. Huet, Revue Trimestrielle de Droit Civil 1986 p. 122. A. Lacabarats, La loi n 85-677 du 05 juil 1985 Gaz Pal 1987. I . doc. 79 
The solution was unsatisfactory. In practice, the plaintiff was obliged to invest a major capital sum in improvements to the old house, which perhaps would otherwise not have be spent; and it practically ran the risk of preventing reconstruction if the necessary capital was unavailable. For this reason the Cour de Cassation finally held that in such a case it could take into account the wear and tear.

In cases of damage to a vehicle, the following difficulty presents itself. In practice, when returning a car to its original condition is more costly than replacing it with a vehicle of the same type, age and condition, can the plaintiff demand that the car be returned to its original condition?

This is still a point which leads to disagrement amongst the Chambers of the Court of Cassation; the Criminal Chamber has held the affirmative, whilst the second Civil Chamber the negative.

The Civil Chamber considers that the cost to return the car to its original condition can only be awarded to the victim when that amount is less than the monetary value of the car. However, it has been held that this value does not coincide with the true monetary value of the car: one should therefore withhold not the price the plaintiff would have been able to get for their car if he had sold it, because he was not selling it, but the sum that must be spent in order to acquire an equivalent model. And to determine this sum it is not necessary to hold to the prices in the Argus second-hand car guide, which carry no official authority and, for certain models, are often at odds with the real state of the second-hand market. Therefore, the principle according to which the victim must be returned to the position in which he would find himself if the accident had not taken place, was respected ${ }^{39}$.

On the premise that the compensation cannot be greater than the loss, a fallacious conclusion has been deduced in the past, i.e: the denial of both the insurance money and the compensation from the defendant. It was held that where the value of the damage is covered by an insurance policy the damage no longer exists. The victim can claim from the defendant only the surplus not covered by the policy. However, it has been noted that this was a mistake. In effect the insurance policy does not repair the damage; it has no origin in the damage itself. It represents a reimbursement from the premiums paid by the insured and hence it does not stem from the same cause ${ }^{40}$. The only limitation to have an effect in similar situations applies to benefits paid by Social Security, pensions and incorporated associations such as friendly societies. That is to say all payments by the third parties must

39 Cass Civ II 18 fev 1976 D S 1976 Somm 43. Cass Civ II 17 mars 1977 Bull Civ II n 89. Cass Civ .I. 06 janvier 1987 Somm 332 obs Groutel. H. V. Amouroux , De l'indemnisation confisquée à la reconnaissance de la valeur de remplacement : la révolution silencieuse de l'assurance automobile - Gaz Pal. 04 mai 1991. 
be deducted from the damages awarded to the plaintiff, such parties' position being similar to that of a general insurer where the law subrogates the rights of the insured ${ }^{41}$.

While it is clear that indemnity principles guide the principle of compensation in French law, a serious difficulty arises with the assessment of damages when it concerns the evaluation of physical injury or emotional harm. Such damages cannot be counted in terms of money. Neither statute nor case law defines emotional harm and therefore no basis exists for determining the damages to be awarded. If for example an accident has led to the victim losing an arm or a leg, the loss resulting from the requisite treatment and incapacity to work can be assessed, but not that which results from loss of looks or sexual ability. Assessment will of necessity be arbitrary. Therefore large discrepancies can appear between the different courts, all the more so when it concerns a question of fact is involved, as the Cour de Cassation cannot intervene and ensure some consistency in the decisions ${ }^{42}$. It is nevertheless true that to enable a certain harmony to be achieved the appeal courts are accustomed to publish tables which sum up the collective decisions in the particular field ${ }^{43}$ "In concreto" assessment and evaluation of the loss, and hence the compensation which follows from it, prohibits any reference to pre-established tables. Nevertheless, the court appointed experts have a tendency to make use of tables which are more or less official ${ }^{44}$. Since expert opinions are not binding on the judges, practice shows that at least as to the extent of the loss, they refer to the expert opinion most of the time; only the quantum of the award is a matter which changes according to the judge's personal standards ${ }^{45}$. It happens no less that the judges in principle in their evaluations distinguish with precision between the elements of the loss from knowledge of the time the plaintiff was incapacitated for work, long term partial disability, the suffering endured (pretium doloris), to aesthetic harm and

41 F. Zenati, Revue Trim Droit Civ 1985 p. 798. Jurisclasseur Resp. Civ. op. cit. fasc 230-2. Cass Civ .1e 05 juin 1967 Bull I n ${ }^{\circ}$ 198. Paris 13 déc 1965 JCP 19866, 14784 , note Rodiere. see Y. Lambert Faivre, Le droit et la morale dans l'indemnisation des dommages corporels - Dalloz 1992 Chronique 32 p. 165 à 168. CA Paris 3 mai 1994, Gaz.Pal. 94, 1, p.17. Bull I n 198.

42 M. Le Roy, L' évaluation du préjudice corporel, Litec 10è Ed 1987. R. Barrot, Le rôle du médecin et du juge dans l'indemnisation du dommage corporel, Rev Fse du Dommage Corporel ,1983-13-24.

43 See Le Roy above n28, and Jurisclasseur Resp. Civ. Fasc. 202-4 et 202-5.

44 See C. Rousseau, Commentaire sur le barème "Droit Commun" dit du Concours Médical , Gaz. Pal. 1994,1, doctr.p 29.

45 It is noticeable when chidren are the victims, see Margeat et Picard, La réparation du dommage chez l'enfant , GP 1981-I-Doct. 254 
loss of appearance. Moreover when all losses are merged to grant a lump sum, the Court of Cassation considers that a Court of Appeal is not obliged to detail all the losses ${ }^{46}$.

This is particularly necessary since the law of 27 December 1973 which has limited the recourse of Social Security against those third parties responsible for sums to redress elements of the loss covered by itself.

\section{$B$ The assessment of the amount of the loss}

To resolve this question, attention must be paid to distinguishing the two periods in the course of which variation can occur, be that before the award of compensation or afterwards.

\section{Assessing the loss}

Take for example, the case where the loss has varied since the day it was caused and the date of the decision awarding the compensation. In effect the case law has considered that the assessment of damages and interest to be awarded should happen as at the date of final judgement and not at the date when the damage occurred ${ }^{47}$.

Assessment at the date of the decision will have as a feature the taking into consideration of any consolidation of the loss. For example, the position of the victim improves, or, to the contrary, it has been aggravated since the accident. In this case, there is no doubt that the court must take into consideration the loss as it stands at the date of judgement taking account of the improvement or aggravation ${ }^{48}$. The response will be different, however, in cases which concern a change in the assessment of the loss due to monetary fluctuations.

Under the notions of equity, the following considerations can change the valuation: ${ }^{49}$

- the plaintiff has the right to total compensation. It is unjust that the victim has to suffer the consequences of an increase in price or the slowness of justice.

- if the plaintiff has replaced the possession since the time of the accident, he or she has not incurred the price increase. But what if he or she waited as he or she was not sure of obtaining any compensation, or because he or she did not have the requisite sum of money?

46 Cass 1è, Civ 16 juillet 1991, JCP 91 - Ed G IV p. 367. This decision has been criticised since it reduces the possibilities for the Court of Cassation, to control the appreciation made by the lower court. See Viney, JCP ,Ed $\mathrm{G} \mathrm{n}^{\circ} 13 \mathrm{n}^{\circ} 3572$

47 Derrida, L'évaluation du préjudice au jour de sa réparation JCP 1951-I-918.

48 Cass Civ 28 dec 1942 - Gaz Pal 1943-I-97.

49 Req 21 mai 1928 D H 1928 - 366. Cass Civ 2e 03 mars 1982 Gaz.Pal 03-04 nov 1982 note F.C. 
In legal theory, this does not prevent the serious conflict of assessment of a loss at the time of judgment with the principle that the debt exists from the moment the loss occurs; if the debt exists at that moment, how can its value subsequently increase? To resolve this, it is proposed to distinguish between the obligation to repair and the obligation to pay compensation. The obligation to repair comes into being at the same instant as the loss, which explains why the debt can be transmitted to heirs. But this duty to repair is transformed at the time of judgment into a duty to pay compensation. It is therefore at this time that the amount must be fixed.

After much indecision, the case law settled on the idea of assessment as at the date of judgement, the Criminal Chamber of the Cour of Cassation having held that the assessment in appeal cases must be made as at the date of the original judgement. However, certain adjustments to the rule have been considered: ${ }^{50}$

- it must be decided whether the plaintiff has proceeded to repair or replacement before the judgement. In this case, compensation must be fixed at the date or repair or replacement ${ }^{51}$.

- the same applies if the plaintiff has refused a reasonable settlement offer, and thus prosecutes a vexatious action. Assessment will be fixed at the date of the offer ${ }^{52}$.

- in cases of loss or deprivation of a possession, a case in the Criminal Chamber of the Cour of Cassation of 6 June 1946, while restating the rule, did not apply to stolen share certificates, which were worth less at the time of judgement than at the time of the theft. It was thought that the plaintiff could have sold them without waiting for the drop in price $^{53}$.

\section{Review of the loss}

It can turn out that the compensation no longer corresponds with the actual loss. In such circumstances where the cost of living or the value of the annuity has varied. Is it possible to later revise the amount of damages fixed by the court's decision?

If one considers the change in the nature of a loss, the questions principally arise, although not exclusively, for physical harm. The case law states that if the state of the victim worsens an increase in the level of compensation can be obtained. The Court of

50 Cass Crim 4 mai 1979 Gaz Pal 1980. J. 90

51 Colmar 2 and 9 avril 1954 JCP 1954 II - 8133, note Lyon-Caen. Cass 2è Civ 19 nov 1975 D- 1976 - 137 , note Le Tourneau.

52 Paris 16 mars 1951 JCP 1951-6182.

53 Cass Crim 6 juin 1946 D - 1947 - 234, note Savatier. 
Cassation admits in principle, that the review is permitted because the authority of that which was previously adjudged rests solely on the loss which was then certain, and not on the complementary loss which was only possible, or which was not even suspected. However, if the position of the victim improves, the person responsible for the loss cannot obtain a reduction in damages. It is considered that this is contrary to the authority of the finding. It can only be otherwise if the judges have held that they were only stating the actual condition of loss and hence the right to review it has been formally set aside in the original judgement ${ }^{54}$.

If one considers the variation in quantum of the loss, it will be noted that in practice it is a matter solely of an increase following monetary depreciation and the question arises above all in cases of invalid's annuities.

The doctrine of the res judicata is contrary to the subsequent review of the decision. Moreover this modification gives rise to a serious practical difficulty because very often the defendant will have paid a capital sum to a company for the annuity which will maintain the operation of the annuity in compensation. But the absence of review is serious for the plaintiff, who sees his resources constantly diminishing. A law of 24 March $1951^{55}$, brought about increases in life interests executed for awards of damages prior to 1 January 1949. This law affects the financing of those annuities whose operation is the responsibility of insurance companies.

To resolve the problem, the courts asked whether they could not in their judgements retain the possibility of a later review directly related to the cost of living and order an indexed annuity. The Court of Cassation was at first opposed to this and put forward two arguments:

1 It invoked the authority of the res judicata. However, there is no breach of the authority of the res judicata if the original decision has retained the possibility of a review, all the more, so if it has even determined the nature of the indexation so that it is not necessary to go before the court again ${ }^{56}$.

2 It also invoked the absence of a line of causation between the fault and the increase in the monetary assessment of the compensation. However, it should be noted that the line of causation exists, when the damage remains the same. it is therefore only its monetary expression which varies.

54 S. Brousseau, Le point sur l'indemnisation par rentes indexées, JCP 1977-I-2855.

55 Modified by another law of 9 April 1953.

56 Cass Soc 2 mai 1952 JCP 52 Ed G II- 6974, note Frejaville. Cass Crim 5 juil 1961 JCP 61 Ed G II - 12369, note P.E. Gaz Pal 1961, 2248. 
In reality, analysis of the idea which underlies the decisions of the Court of Cassation showed that the courts were not failing in their duty by taking account of monetary norms. This argument finds its strength in the fact that the legislature itself is has been obliged to take account of depreciation.

The main criticisms which can be made of this case law concern:

- the legal sphere: the principle of total compensation requires an annuity which replaces in real terms the salary lost by the victim; now the salary would increase as a function of the rise in the cost of living.

- the practical sphere: the case law condemns accident victims with physical injuries up to total disability to fall progressively below the poverty line. Hence the resistance of the lower courts to the doctrine. The Court of Cassation has made a sudden change in two cases of 6 November 1974, which held that judges could index annuities ${ }^{57}$. Nevertheless, under pressure from the insurance companies, the legislature has in its own manner intervened through a law of 27 December 1974 which has seriously limited the scope of the decisions of the Court of Cassation of 6 November 1974, by authorising indexation only for disabilities of $75 \%$ or more ${ }^{58}$.

- Outside the domain of the law of 27 December 1974, as amended in 1985, the judge is free to index the annuity according to the index which appears to her to be the most suitable. But it is not possible to index an annuity which was not so originally 59 .

\section{Some comments about the future of French civil liberty}

"By tradition, one considers that the rational of civil liability is based on three roots which according to the circumstances can intervene autonomously or more often, are combined: the fault, the risk and the guaranty ${ }^{60}$. However, the study of the evolution of civil liability until its origin clearly indicates a gradual and continuous transfer from the fault to the guarantee. Being obliged to cope with the society's transformations and the new requirements to provide a comprehensive compensation to the victims, doctrine and caselaw both conceived different grounds for liability and reconsidered the position of the fault and its traditional role. But this internal crisis is not the most important one. More

57 JCP 75-II-17978, Concl. Geyout, note Savatier, Rev Trim Dr Civ 1975-114 et 549 ob. DURRY.

58 The "Badinter" law repealed this provision in 1985. Article 43 of the law of 05 July 1985 and article 1 of the decree $n^{\circ} 86-973$ of 08 August 1986.

59 Cass Civ 17 avril 1975 D S 1976, note Sharaf el Dine.

60 P. Guiho and G. Peyrard. Droit Civil IV. les Obligations. Tome I, Les Sources (L'Hermes.1991) 418. 
disturbing is the role of the new mechanisms of collective indemnification which are seriously challenging the future of the civil liability ${ }^{61}$.

\section{A The role of the fault}

Today everybody agrees on the superiority of the objective approach of the concept of liability and on the inadequacy of the concept of fault to provide an acceptable criterion for an adequate compensation. But even when liability based on fault is concerned, many criticisms are levelled. All the criticisms led to an important retreat from the concept of fault. Strict liability became gradually the most important field of civil liability. However there are still some legal areas where the concept of fault still operates ${ }^{62}$.

\section{Evolution of the concept of fault.}

Firstly the distortion of the concept of fault itself is striking. To ensure an adequate compensation for the victims, courts are now obliged to take into consideration simple errors, consequences of clumsiness or a bad reflex. Judges are now considering what has been called a "dust of fault" just to provide indemnification to the victim. A.Tunc has vigorously denounced such trend and the confusion between fault and error ${ }^{63}$. He insisted on the fact that statistically speaking there is always a fringe of unavoidable and humanly excusable acts that even the wisest person could not control. Moreover civil fault has lost the main part of its social value. It is no longer a way to control human behaviour. One may notice the same influence on the liabilities based on fault, the persons liable being assured persons as well.

Articles 1382 and 1383 are still valid and moreover some sectors of the civil liability are governed by the concept of fault ${ }^{64}$. It will still be applied when:

- a private right is involved, such as a breach of the right of privacy, or reputation,

- a property right is violated,

- an intellectual property right is concerned ${ }^{65}$,

- unfair trading or competition must be compensated.

61 Y. Lambert-Faivre, L'évolution de la reponsabilité civile d'une dette de responsabilité à une créance d'indemnisation. Rev.trim.de Dr.Civ. 86(1) Jan/March 87.

62 P. Jourdain, Les principes de la responsabilité civile (Connaissance du Droit, Dalloz, 1992$) 17$.

63 A.Tunc, Responsabilité (en général), Encyclopédie Dalloz n ${ }^{\circ} 1$ and seq.

64 "To limit the domain of the civil liability 's scope to the fault is a myth......but it does not mean that the fault should be banished from the civil liability " G. Viney. R.I.D.C. 1976. p. 581.

65 On the intellectual property rights, see Y-L Sage "The French Intellectual Property Code 1992- The author's rights of disclosure and of reconsideration" New Zealand Intellectual Property Law Journal, February 1996. 
But it is also in its role of controlling the victim that the concept of fault keeps its full strength. The current case-law continues to consider that the victim's fault must produce a reduction in compensation and even if the 1985 law on road accidents has to some extents modified this principle by imposing a fault of a certain level of importance, it has not completely disappeared ${ }^{66}$.

\section{The role of the insurance contracts and of the collective compensation schemes on the civil liability}

The evolution of French civil liability was actually made possible by the growing impact of the insurance contracts on civil liability ${ }^{67}$. The insurance on civil liability emerged at the same time as the concept of objective liability. Its main purpose is to discharge the person responsible from the final payment while providing a wrongdoer full coverage against the pecuniary consequences linked to his liability. The insurance of civil liability is at the same time the consequence and the raison for the fast growth of the liability itself. It is obvious that without insurance, courts would be reluctant to sentence a defendant to a high amount of money for a liability based on the absence of fault. If it is possible today to focus on the victims' interests, it is not only because damages are more important, but mainly because in almost all circumstances, the defendant has the opportunity to contract an insurance or is obliged to have one. Therefore the final burden of the liability is supported by the entire community through the premiums paid by the insured. However the insurance contracts on liability, induce some side effects which ultimately disturb the concept of liability itself.

a) First, the tortfeasor, being discharged of the final payment, enjoys an almost total impunity.

b) Second, positive law tends to connect the liability to the ability to subscribe an insurance contract, especially when it is necessary to determine as responsible someone who is different of the direct actor.

c) Third, in a liability trial it is the insurer who has the control of the procedure ${ }^{68}$.

The liability looks like a simple support for the subscription of an insurance contrat. If the person liable remain the original debtor, he could be also an ineffective one. By sharing the burden of the damage's cost, the insurance for civil liability represents the first expression of the collectivisation of the liability. However it is still an indirect liability as

66 Ch.Larroumet, L'indemnisation des victimes d'accident de la circulation, l'amalgame de la responsabilité civile et de l'indemnisation automatique,Dalloz 1985, Chr 237

67 P. Jourdain.Les principes de la responsabilité civile. op. cit p.12.

68 V.C. Freyria, La direction du procès en responsabilité par l'assureur, JCP 1954 - I - 1196. 
long as the compensation is subordinated to a preliminary declaration of liability made by the assured person.

By contrast some institutions offer direct and collective compensation to the victims ${ }^{69}$. And along with the Social Security, specific guarantees are provided by the collectivity for traffic or hunting accidents, for victims of criminal or terrorists acts ${ }^{70}$ and more recently for the victims of blood transfusion ${ }^{71}$. These provide indemnification for certain kinds of damage without having to consider first who is responsible. Therefore the burden of responsibility becomes a concern of social justice of the community ${ }^{72}$. Civil liability is diluted within the social group and its existence is finally jeopardised.

\section{Conclusion}

The current crisis of civil liability is not due to the crisis with fault ${ }^{73}$. It is first due to the challenging influence of the systems of compensation based on a social analysis ${ }^{74}$. When the person liable is also an insured person, the insurer will be the real debtor. The liability becomes a simple result of the insurance contract and is only necessary to designate the insurer who will compensate the victim. When the collectivity is directly taking in charge the damage, civil liability is fully put aside ${ }^{75}$. The only remaining problem is to determine either the field or the circumstances when the indemnification will occur. Today damages are considered to be social risks, which must be insured by the community and therefore, in such systems it appears natural that any damage has an a priori vocation to be compensated. The French conception of the fault and its consequences in the civil liability domain is not unique. It represents only one attempt among others to redefine the role which should be granted to the fault ${ }^{76}$. For example, the New Zealand conception, has drastically

G. Baron, Le fonds de garantie automobile, Rev. Trim. Dr. Civ. 1974 p. 250. G. Durry and F Chapuisat, Fonds de Garantie Automobile, Encyclopédie Dalloz Civil , $n^{\circ} 22$ and seq.

J. F. Renucci, L'indemnisation des victimes d'actes de terrorisme, D. 1987, Chronique 197.

71 Y.Lambert-Faivre, L'indemnisation des victimes post-transfusionnelles du SIDA: hier, aujourd'hui et demain......R.T.D Civ.92 (1).January-March 1993. p 8 and seq. M-L Morencais-Demeester, Contamination par transfusion du virus du SIDA: Responsabilité et indemnisation, D, 1992, Chr. p. 190.

72 P. Escande, A propos de la loi $\mathrm{n}^{\circ}$ 83-608 du 08 juillet 1983 . D. 1983, 351.

73 P. Le Tourneau, La verdeur de la faute dans la responsabilité civile (ou de la relativité de son déclin), Rev.Trim. Dr. Civ.1988.505.

L.Bach, Reflexions sur le probléme du fondement de la responsabilité civile, Rev.Trim.Civ.1977, $13 \mathrm{~s}$ et $221 \mathrm{~s}$.

F.Zenati ,Revue trimestrielle Droit Civil 1985, p. 793.

A.Tunc, Où va la responsabilité civile aux Etats-Unis. R.I.D.C.1989,711; Quatorze ans aprés; le systeme d'indemnisation néo-zélandais, R.I.D. C. 1. 1989, p. 140. Brown, Deterrence in tort and no-fault: the NewZealand experience 73, Cal.1.Rev. 976 (1985). A.Levasseur, Droit des Etats-Unis Dalloz, 110. T. G Ison, "Changes to the Accident compensation system: An international perspective" (1993) 23 VUWLR 1. 
reduced the importance of the fault in civil liability. Even if none of these conceptions are fully conclusive, the current trend provides better chances for the victims to obtain a fear compensation for their damages.

\section{La responsabilité délictuelle et quasi-délictuelle en droit français: Aperçu des principes régissant l'indemnisation du dommage et commentaires sur le rôle de la faute}

Concept multiforme au contenu "ambiguë", la responsabilité civile contient néanmoins toujours dans le droit français, l'idée d'un dommage et de sa réparation et de l'indemnisation des victimes. Dans cette perpective, la responsabilité est couramment définie comme l'obligation mise a la charge d'un responsable de réparer les dommages causés à autrui. Pris au sens large, le processus indemnitaire peut intéresser la société et l'individu séparément ou les deux à la fois. Si l'on ramène uniquement la responsabilité civile à la seule finalité de l'indemnisation de la victime, on remarque qu'aujourd'hui:

a) qu'est apparu un véritable droit à indemnisation conféré à la victime. En d'autres termes, les risques d'insolvabilité du débiteur de l'obligation indemnitaire ne doivent plus peser sur la victime. Les assurances privées ou l'État, donc des tiers au dommage lui-même, interviennent dans le processus d'indemnisation et se substituent maintenant de plus en plus fréquemment au débiteur d'origine. Le Conseil Constitutionel a rappellé que "le droit français ne comporte en aucune manière de régime soustrayant à toute réparation les dommages résultant de fautes civiles imputables à des personnes physiques ou morales de droit privé quelle que soit la gravité de ces fautes". Selon ce principe la créance de réparation existe dès le moment où le dommage est réalisé. En matière délictuelle le droit à réparation existera dès la réalisation du dommage. Deux procédés de réparation sont envisageables. La réparation peut être faite soit en nature, soit en argent. Si cette dernière modalité de réparation est sur le plan théorique facilement concevable, sa mise en oeuvre quant à l'évaluation du quantum notamment, demeurent toutefois soumise à une appréciation subjective des tribunaux. La réparation en nature demeure plus délicate à mettre en place et ne constitue peut-être pas un véritable mode de réparation. La finalité première de la réparation est d'assurer qu'elle soit équivalente au préjudice. Mais si le principe est simple dans sa formulation, son application soulève des difficultés lorsque le montant du préjudice fluctue.

b) qu'une place nouvelle est maintenant affectée à la faute dans le système de la responsabilité civile en France. Certes, le système français est loin d'être le seul à avoir assujetti à la faute une place différente à celle qui lui était traditionnellement dévolue, et à bien y regarder, il ne représente que l'une des différentes tentatives de la redéfinition de la place de la faute dans la responsabilité civile. Ainsi les législations étrangères 
offrent à des degrés divers et avec des résultats plus ou moins heureux tant en théorie qu'en pratique, d'autres exemples de redefinition. Ainsi, pour ne retenir qu'eux, le système Néo-Zélandais et le système suédois, ont instauré des systèmes de responsabilité civile d'où la faute à quasiment disparue. Le systeme français n'est donc nullement original et novateur. 